\title{
Toxicity and Protective Effects of Cerium Oxide Nanoparticles (Nanoceria) Depending on Their Preparation Method, Particle Size, Cell Type, and Exposure Route
}

\author{
Jacinthe Gagnon*[a] and Katharina M. Fromm*[a]
}

Keywords: Nanoparticles / Cerium / Toxicity / Antioxidants / Radiation protection / Experimental design

Nanoceria (cerium oxide nanoparticles) toxicity is currently a concern because of its use in motor vehicles in order to reduce carbon monoxide $(\mathrm{CO})$, nitrogen oxides $\left(\mathrm{NO}_{\mathrm{x}}\right)$, and hydrocarbons in exhaust gases. In addition, many questions arise with respect to its biomedical applications exploiting its potential to protect cells against irradiation and oxidative stress. Indeed, toxicology studies on nanoceria report results that seem contradictory, demonstrating toxic effects in some studies, protective effects in others, and sometimes little or no effect at all. The variability in the experimental setups and particle characterization makes these studies difficult to compare and the toxicity of newly developed nanoceria materials challenging to predict. This microreview aims to compare the toxicity of nanoceria in terms of preparation method, particle size, concentration, host organism, and exposure method.

\section{Introduction}

The increased use of nanoparticles (NPs) and nanoparticle-based materials raises many concerns about their impact on health. Some reviews ${ }^{[1-3]}$ have commented this issue for various such materials, demonstrating the importance of the research on biosafety. However, as noted in most of these reviews, toxicity tests are often hardly reproducible among different research groups. For example, the size of $\mathrm{NPs},{ }^{[4]}$ their surface properties, ${ }^{[5]}$ the type of cells, ${ }^{[4]}$ and the

[a] Department of Chemistry and Fribourg Center

for Nanomaterials, University of Fribourg

Chemin du Musée 9, 1700 Fribourg, Switzerland

E-mail: katharina.fromm@unifr.ch

http://www.chem.unifr.ch/kf/ exposure method ${ }^{[6]}$ all influence the outcome of studies on their toxicity in such a way that it may lead to different results. On the other hand, the increased use of NPs and nanoparticulate materials as well as their potential in various applications render the study of their toxicity highly essential.

Nanoparticulate materials based on ceria (cerium oxide, $\mathrm{CeO}_{2}$ ) have many applications in diverse fields, including petroleum refining, polishing agents, and coatings. ${ }^{[7]}$ Nanoceria is a promising material for energy-related applications such as in fuel cells, hydrogen production and purification, and water splitting. ${ }^{\left[{ }^{8}\right.}$ Its use in three-way catalysts, especially as the mixed oxide, $\mathrm{CeO}_{2}-\mathrm{ZrO}_{2}$, in motor vehicles, has proven very valuable for environmental issues, as it reduces the emission of polluting gases by controlling the air-

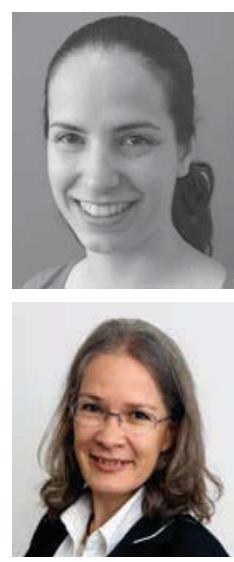

Jacinthe Gagnon was born in Québec (Canada) in 1982. She studied Biochemistry at Concordia University (Canada) and obtained her B.Sc. in 2006. She pursued her studies in the field of Biomaterials at the University of Ulm (Germany) and received her M.Sc. in Advanced Materials in 2008. Afterwards she held a Ph.D. position on the nanoencapsulation of silver-based antimicrobial drugs for biomaterial applications at the University of Fribourg (Switzerland) under the supervision of Prof. Katharina M. Fromm. She obtained her Ph.D. in Chemistry in 2014. Dr Gagnon currently holds a postdoctoral position in Biochemistry at the Institut National de la Recherche Scientifique (INRS) - Armand-Frappier Institute (Canada) on the structural characterization of human RNases.

Katharina M. Fromm is full professor for chemistry at the University of Fribourg, Switzerland, since 2006. After a PhD degree from the University of Karlsruhe, Germany, and postdoctoral stays at the Universities of Tübingen, Germany, and Strasbourg, France, she joined the University of Geneva for her habilitation. In 2002 she was awarded a stipend within the Emmy Noether Program II by the Deutsche Forschungsgemeinschaft and in 2003 a Research Professorship by the Swiss National Science Foundation at the University of Basel. In 2013, she was elected Fellow of the American Chemical Society. Since 2011, she is member of the Research Council of the Swiss National Science Foundation. 
to-fuel ratio thanks to its oxygen-storage capacity. It thus enables the simultaneous oxidation of $\mathrm{CO}$ and hydrocarbons and the reduction of $\mathrm{NO} .^{[8,9]}$ Ceria nanoparticles were demonstrated to have no significant adverse effects on the cytotoxicity in a $3 \mathrm{D}$ in vitro co-culture model of the epithelial airway barrier for diesel exhaust exposure in such a way that their use as a fuel-borne catalyst can be advantageous, though its long-term effects still remain to be elucidated. ${ }^{[10]}$ They have also been proposed for biomedical applications, for example in sun creams ${ }^{[11]}$ and more recently in the form of nanocontainers as drug carriers for the prevention of, for example, implant infections. ${ }^{[12]}$ Furthermore, it was demonstrated that ceria NPs can protect cells against irradiation and oxidative stress; ${ }^{[13,14]}$ hence their biological activity and toxicity are of great interest. The present review therefore focuses on the protective and toxic effects of nanoceria and aims to compare some of the variables that can influence the protection or toxicity as reported by various research groups. Yokel et al. ${ }^{[13]}$ compared the biological effects depending on nanoceria size, host subject, and exposure method, whereas Karakoti et al. ${ }^{[14]}$ focused on the effects according to nanoceria preparation methods. We hereby present a more extensive comparison and discussion on both the preparation methods and the experimental setup. We focus on the preparation methods in combination with particle size and concentration, host organism, and exposure method, in order to observe the effects that the particle preparation has on the protective and toxic effects of nanoceria. This extensive and visual comparison, also presented in form of a table, can provide a good starting point for the design of nanoceria materials with more predictable toxicity.

\section{Protective Effects of Ceria Materials}

The key property that makes ceria such an interesting material for biomedical applications is its oxygen-storage capacity. ${ }^{[15,16]}$ In fact, ceria normally contains many defects, that is, oxygen vacancies, which enable it to rapidly give up or take up oxygen atoms in a reversible manner. When an oxygen atom is released according to Equation (1), two of the four neighboring $\mathrm{Ce}^{4+}$ atoms get reduced to their +3 oxidation state in order to equilibrate the charge, as depicted in Figure 1. ${ }^{[16,17]}$

$\mathrm{CeO}_{2} \rightleftharpoons \mathrm{CeO}_{2-x}+1 / 2 x \mathrm{O}_{2}(\mathrm{~g})$ where $0 \leq x \leq 0.5$

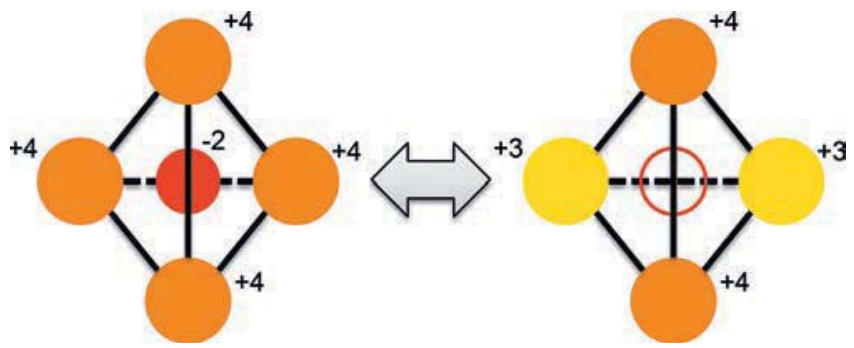

Figure 1. Simplified schematic representation of the charge redistribution in $\mathrm{CeO}_{2}$ upon the occurrence of an oxygen vacancy. Adapted with permission from ref. ${ }^{[16]}$
The remarkable oxygen-storage capacity and antioxidative property of ceria have also been attributed to its radical scavenging, ${ }^{[18]}$ protection against irradiation, ${ }^{[19]}$ and UV-filtering properties. ${ }^{[20]}$ This leads to the protection of eukaryotic cells against oxidative stress, as it was previously reported in many studies. ${ }^{[21,22]} \mathrm{Niu}$ et al. ${ }^{[23]}$ and Korsvik et al. ${ }^{[2]}$ have proposed a mechanism, shown in Equations (2) and (3), by which ceria can scavenge radicals thanks to its redox potential.

$\mathrm{O}_{2}^{--}+\mathrm{Ce}^{4+} \rightarrow \mathrm{O}_{2}+\mathrm{Ce}^{3+}$

$\mathrm{O}_{2}{ }^{--}+\mathrm{Ce}^{3+}+2 \mathrm{H}^{+} \rightarrow \mathrm{H}_{2} \mathrm{O}_{2}+\mathrm{Ce}^{4+}$

However, the redox potential of ceria might also lead to toxic pro-oxidative effects, ${ }^{[25,26]}$ (see Table 1) and it was recently demonstrated that the radioprotection efficacy of nanoceria through free-radical scavenging is also dependent on the X-ray radiation spectra. ${ }^{[27]}$ It was furthermore shown that the smaller the size of the nanoceria particles, the higher the amount of $\mathrm{Ce}^{3+}$ and hence that of oxygen defects in the structure and on the surface of the particles. ${ }^{[7]}$

\section{Toxicity of Nanoceria}

It is generally assumed that toxicity increases as the NP size gets smaller. ${ }^{[28]}$ This can be explained by the fact that cellular uptake is facilitated for smaller NPs and they are therefore more likely to be distributed in the blood stream or even in the central nervous system. In addition, smaller particles have a larger surface area per mass unit in such a way that they are potentially more active. ${ }^{[28,29]}$ In the case of nanoceria, a larger ratio of surface area to volume leads to a larger surface $\mathrm{Ce}^{3+} / \mathrm{Ce}^{4+}$ ratio, which could be related to a higher toxicity for smaller ceria NPs. ${ }^{[6]}$ However, this is not always applicable for all ceria materials. In fact, a study demonstrated that larger ceria particles can have a higher toxicity towards eukaryotic cells. ${ }^{[30]}$ Another in vivo study demonstrated that inhaled ceria nanomaterials are more toxic than ceria micromaterials in terms of mass concentration, but less toxic in terms of surface area concentration. When the authors expressed their results in terms of particle number, then both materials had a similar toxicity. ${ }^{[31]}$ The lower toxicity with smaller ceria particle size can also be explained by the higher tendency of smaller NPs to form agglomerates. ${ }^{[32]}$ It is also well known that the surface properties, such as the zeta potential, of NPs play a key role in their biocompatibility. ${ }^{[33]}$ The zeta potential of particles can be modified by changing, for example, the $\mathrm{pH}$ of the solution $^{[34]}$ or by using a coating. ${ }^{[35]}$ Kumar et al. ${ }^{[32]}$ have reviewed the way physicochemical properties of the tested nanoceria can influence the results of the cytotoxic studies. In short, they noted that a minor modification in the synthesis route may have a major impact on the biological activity and toxicity of ceria and pointed out that reproducibility in nanomaterials synthesis often constitutes a challenge. Kumar et al. ${ }^{[32]}$ also discussed many gaps that need to be filled with regard to nanoceria toxicity. For example, a better understanding of the influence of the precursor's 
purity, nanoceria morphology, binding sites, and long-term biotransformation in vivo is still strongly needed.

Some other studies ${ }^{[13,36,37]}$ also reported a low toxicity of ceria towards eukaryotic cells, even though no protection effect was observed. For example, Gaiser et al. ${ }^{[36]}$ demonstrated that, even though they adhered to the cell membrane and entered the cells, ceria NPs that were smaller than $25 \mathrm{~nm}$ or had a size between 1 and $5 \mu \mathrm{m}$ did not show any significant cytotoxicity. A study by Yokel et al., ${ }^{[38]}$ who injected $30 \mathrm{~nm}$ nanoceria intravenously into the blood of rats, demonstrated that this material did not cross the blood-brain barrier (BBB). They also observed that nanoceria remained in the body, especially in the spleen, liver, and bone marrow, for long time periods of up to 90 days and that the bigger-sized nanoceria $(55 \mathrm{~nm})$ tended to aggregate at the site of injection rather than being distributed in the body. ${ }^{[13,38]}$ Their observations are in accordance with results reported by other research groups. ${ }^{[25]}$ Nanoceria has also been reported to have a low acute toxicity towards Calu-3 lung epithelial cells and Raw264.7 macrophages and to have no effect on transepithelial electrical resistance in such a way that nanoceria did not damage the epithelial barrier. $^{[37]}$

Some publications reported a time- and dose-dependent toxicity of ceria nanomaterials. ${ }^{[38-40]}$ De Marzi et al., ${ }^{[22]}$ who studied the one-day and ten-day effects of ceria exposure on different cell lines, found that the toxicity assays are greatly dependent on the systems being studied. In fact, they observed that ceria had different effects according to the cell line of interest, the human adenocarcinomic alveolar basal epithelial A549 cell line being the most sensitive to the presence of ceria at low concentrations. Three different studies on nanoceria toxicity against A549 cells (Table 1) all demonstrated adverse effects ${ }^{[12,41,42]}$ and are thus in accordance with the observations of De Marzi et al., ${ }^{[22]}$ who did not observe any toxic effect of ceria after 24 hours of exposure but reported a genotoxic effect for all cell lines after 10 days.

The synthesis protocol, which dictates, for example, the particle size, structure, and surface properties of ceria, also contributes to their effect on biological systems. Karakoti et al. ${ }^{[14]}$ have reviewed the effect of the preparation method on ceria toxicity and have indicated that a synthesis at low temperature often leads to less toxic and even more antioxidative ceria particles. This observation was partly explained by the fact that the chemicals used in the synthesis of the ceria nanomaterials influence the zeta potential, ${ }^{[34]}$ which in turn influences their aggregation behavior, protein adsorption, and cytotoxicity. ${ }^{[34,43]}$ They also found that the effects of chemicals can be altered by high temperatures. This was also observed by Peng et al., ${ }^{[44]}$ who compared the cytotoxicity of nanoceria prepared by either precipitation or hydrothermal methods. Nanoceria prepared by precipitation formed smaller aggregates in such a way that their acute inflammatory effect was higher and their deposition in the lungs was faster. On the other hand, the hydrothermally prepared nanoceria produced more reactive oxygen species (ROS), causing inflammation and cytotoxicity. This seems to be in contrast with the fact that nanoceria particles prepared at high temperatures tend to be bigger, more dense, and to have fewer oxygen vacancies and defects. ${ }^{[14]}$ A shape effect was reported by $\mathrm{Ji}$ et al., ${ }^{[45]}$ whereby long ceria nanorods (greater than or equal to $200 \mathrm{~nm}$ ) induced inflammatory responses while short ceria nanorods were nontoxic.

Hussain et al. ${ }^{[46]}$ suggested many possible toxic effects of ceria on human peripheral blood monocytes. In their ex vivo study, they first observed an up-regulation in autophagy caused by an inhibition of p53 proteins, which are the proteins that regulate the cell cycle and prevent cancer formation, leading to cell death. In addition to that, they observed the swelling and elongation of mitochondria following exposure to nanoceria, which further leads to apoptosis. Induced apoptosis due to nanoceria exposure was also observed by other research groups. ${ }^{[12,47]}$ This effect is attributed to an overproduction of ROS and a diminution of the antioxidant species glutathione (GSH). ${ }^{[47]}$

The uptake kinetics plays a key role in interpreting the toxicity of materials. Some cells can rapidly internalize ceria nanoparticles. For example, 24 hours after exposure to aerosolized ceria nanoparticles, $80 \%$ of the nanoparticles were detected intracellularly in A549 lung cells, and the rate of nanoceria internalization is limited by the particle mass transport. ${ }^{[48]}$ Within cells, ceria nanoparticles tend to agglomerate. ${ }^{[48,49]}$ Cytotoxic effects of nanoceria can be greatly reduced by preventing the internalization of the NPs into cells, for example by encapsulating them into a hydrogel. Weaver and Stabler ${ }^{[50]}$ demonstrated that their alginate hydrogel prevented the phagocytosis of dextran-coated nanoceria and thus reduced their cytotoxicity, while preserving the antioxidative and protective properties of these particles. On the other hand, it was observed that when no cytotoxicity is observed, the cellular uptake can even enhance the protection against ROS, and thus reduce apoptosis. ${ }^{[50]}$

These different reports demonstrated various protective as well as toxic effects for nanoceria, as already pointed out in other reviews on other nanomaterials as well. . $^{[6,28,32,51]}$ Furthermore, the combination of materials, for example the use of nanoceria with other particles such as those in diesel exhaust, may increase their toxicity ${ }^{[52]}$ and render the biosafety of nanoceria more challenging to determine.

\section{Comparison and Discussion}

Table 1 lists representative examples of all reported effects of nanoceria materials according to their preparation method, size, and the tested organism. When available, the effective concentration $\mathrm{EC}_{20}$, that is, the concentration at which the nanoceria material induced a $20 \%$ decrease in cell viability, was provided. This table was partly inspired by the reviews of Yokel et al. ${ }^{[13]}$ and Karakoti et al. ${ }^{[14]}$ The publications in which the method of fabrication and the particle sizes were not specified, in which the nanoceria was purchased from suppliers, or in which the nanoceria is embedded into a matrix were omitted. 
The first observation that can be made by looking at Table 1 is that studies demonstrating protective effects or no adverse effects of ceria are more numerous than those demonstrating negative adverse effects. Among the 44 materials reported in Table 1, 16 (36\%) demonstrated adverse effects, $12(27 \%)$ demonstrated little or no adverse effects and $17(39 \%)$ demonstrated protective effects. Schubert et al. ${ }^{[30]}$ have shown that ceria materials that have a cytotoxic effect on nerve cells can nonetheless be beneficial and protect these cells against harmful irradiation.

Another observation from Table 1 is that, in contrast with the suggestion of Karakoti et al., ${ }^{[14]}$ the method and temperature of preparation are far from being enough to predict the toxicity of ceria nanomaterials, even though these factors contribute to the biological effects of nanoceria. In fact, we do observe a slight relation between the temperature and the biological activity. Among the 17 materials synthesized at high temperatures (above $100{ }^{\circ} \mathrm{C}$ ), 9 $(53 \%)$ had adverse effects, $4(23.5 \%)$ had little effect, and 4 $(23.5 \%)$ had protective effects, whereas among the 27 materials prepared at low temperatures (less than or equal to $\left.100{ }^{\circ} \mathrm{C}\right), 7(26 \%)$ had adverse effects, $8(30 \%)$ had little effect, and $13(48 \%)$ had protective effects. One nanoceria material was considered twice because it had protective ef-

Table 1. Effects of ceria on eukaryotic cells depending on the preparation method, particle size, cell type, and test type.

\begin{tabular}{|c|c|c|c|c|c|c|c|}
\hline Preparation method & Size & Concentration & Test & Host & Exposure method & Effect & Ref. \\
\hline \multicolumn{8}{|l|}{ Adverse effects } \\
\hline $\begin{array}{l}\text { Homogeneous nucleation } \\
\text { at r.t. }\end{array}$ & $20{ }^{\wedge} 3 \mathrm{~nm}$ & $\begin{array}{l}20 \text { to } 140 \mu \mathrm{M}(3.5,10.5 \text {, and } \\
23.3 \mu \mathrm{g} / \mathrm{mL})\end{array}$ & in vitro & $\begin{array}{l}\text { A549 (human lung } \\
\text { cancer cells) }\end{array}$ & Exposure to $\mathrm{CeO}_{2}$ & $\begin{array}{l}\text { Cytotoxicity, oxidative stress. EC } 20 \text { (SRB }{ }^{[b]} \text { and LDH }{ }^{[c]} \text { assays): } \\
\text { between } 0.607 \mu \mathrm{g} / \mathrm{cm}^{2}(3.5 \mu \mathrm{g} / \mathrm{L}) \text { and } 1.82 \mu \mathrm{g} / \mathrm{cm}^{2}(10.5 \mu \mathrm{g} / \mathrm{L}) \text { for } \\
72 \mathrm{~h}\end{array}$ & 1421 \\
\hline $\begin{array}{l}\text { Supercritical synthesis } \\
\text { (temperature not } \\
\text { mentioned) }\end{array}$ & $15,25,30,45 \mathrm{~nm}$ & \multicolumn{2}{|c|}{$10,20,40 \mathrm{ppm}(6000-230000 \mathrm{nM})$ in vitro } & \multicolumn{2}{|c|}{$\begin{array}{l}\text { BEAS-2 (human } \\
\text { bronchial epithelial cells) }\end{array}$} & \multicolumn{2}{|l|}{$\begin{array}{l}\text { Reduced viability and increase in ROS and oxidative stress. } \mathrm{EC}_{20} \\
\text { (MTT assay }{ }^{(\mathrm{fl})} \text { ) : between } 20 \text { and } 40 \mu \mathrm{g} / \mathrm{L} \text { for } 24 \mathrm{~h} \text { and }<20 \mu \mathrm{g} / \mathrm{L} \text { for }{ }^{[39]} \\
48 \text { h or more (for } 30 \text {-nm particles) }\end{array}$} \\
\hline $\begin{array}{l}\text { Supercritical synthesis } \\
\text { (temperature not } \\
\text { mentioned) }\end{array}$ & $\begin{array}{l}15,30 \text { and } 45 \mathrm{~nm} \\
\text { (aggregate sizes: } 76, \\
1588 \text { and } 1588 \mathrm{~nm}, \\
\text { respectively) }\end{array}$ & $1 \mathrm{mg} / \mathrm{L}$ & in vitro & \multicolumn{2}{|c|}{$\begin{array}{l}\text { BEAS-2 (human } \\
\text { bronchial epithelial cells) }\end{array}$} & \multicolumn{2}{|l|}{$\begin{array}{l}\text { Reduced viability and increase in ROS and oxidative stress. } \mathrm{EC}_{20}>\text { [5s] } \\
1 \mathrm{mg} / \mathrm{L} \text { for } 24 \mathrm{~h}\end{array}$} \\
\hline $\begin{array}{l}\text { Aqueous precipitation at } \\
\text { r.t. }\end{array}$ & $\begin{array}{l}7 \mathrm{~nm} \text { (aggregate size: } \\
320^{\wedge} 20 \mathrm{~nm} \text { and } \\
3000^{\wedge} \pm^{\wedge} 400 \mathrm{~nm} \text { in } \\
\text { DMEM }^{(\epsilon)} \text { ) }\end{array}$ & $6^{\wedge} \times \wedge 10^{-6}$ to $0.6 \mathrm{~g} / \mathrm{L}$ & in vitro & $\begin{array}{l}\text { Normal human } \\
\text { fibroblasts from infant } \\
\text { foreskin }\end{array}$ & Exposure to $\mathrm{CeO}_{2}$ & \multicolumn{2}{|l|}{$\begin{array}{l}\text { DNA lesions, pro-oxidative stress. } \mathrm{EC}_{20}\left(\mathrm{WST}-1 \text { assay }{ }^{[0]}\right) \text {; between } \\
6 \mu \mathrm{g} / \mathrm{L}]\end{array}$} \\
\hline $\begin{array}{l}\text { Aqueous precipitation at } \\
\text { r.t. }\end{array}$ & $320 \mathrm{~nm}$ & $\begin{array}{l}0.58 \text { and } 1.17 \mathrm{~g} / \mathrm{L} \text { (ca. } 5.8^{\wedge} \times \wedge 10^{-9} \\
\text { and ca. } 1.17^{\wedge} \times 10^{-8} \mathrm{~g} / \text { cell) }\end{array}$ & in vitro & $\begin{array}{l}\text { Normal human } \\
\text { fibroblasts from infant } \\
\text { foreskin }\end{array}$ & Exposure to $\mathrm{CeO}_{2} \quad \mathrm{I}$ & DNA lesions, pro-oxidative stress; DNA single-strand breaks & [\$\$] \\
\hline Wet chemistry at r.t. & $1 \mu \mathrm{m}$ & $20 \mu \mathrm{g} / \mathrm{mL}$ & in vitro & HT22 (nerve cells) & Exposure to $\mathrm{CeO}_{2}$ & Cytotoxicity observed. $\mathrm{EC}_{20}$ (MTT assay $\left.{ }^{(\mathrm{d})}\right): \leq 20 \mu \mathrm{g} / \mathrm{mL}$ for $20 \mathrm{~h}$ & [00] \\
\hline $\begin{array}{l}\text { Sol-gel synthesis and heat } \\
\text { treatment (up to } 600^{\circ} \mathrm{C} \text { ) }\end{array}$ & $4.7 \wedge \pm^{\wedge} 1.1 \mathrm{~nm}$ & 0 to $175 \mu \mathrm{g} / \mathrm{mL}$ & in vitro & $\begin{array}{l}\text { Neuro2A (murine } \\
\text { neuroblastoma cells) }\end{array}$ & Exposure to $\mathrm{CeO}_{2}$ & $\begin{array}{l}\text { Cytotoxicity observed. } \mathrm{EC}_{20}\left(\mathrm{MTT} \text { assay }{ }^{(\mathrm{d})}\right) \text { : between } 10.93 \text { and } \\
21.87 \mu \mathrm{g} / \mathrm{mL} \text { for } 24 \mathrm{~h}\end{array}$ & [55] \\
\hline $\begin{array}{l}\text { Sol-gel synthesis and heat } \\
\text { treatment at } 600^{\circ} \mathrm{C}\end{array}$ & $175-200 \mathrm{~nm}$ & 0,29 , and $87 \mathrm{~g} / \mathrm{mL}$ & in vitro & $\begin{array}{l}\text { A549 (human lung } \\
\text { cancer cells) }\end{array}$ & Exposure to $\mathrm{CeO}_{2}$ & $\begin{array}{l}\left.\text { Increase apoptosis observed. EC } 20 \text { (LDH assay }{ }^{[\mathrm{c})}\right): 14.5 \mathrm{mg} / \mathrm{cm}^{2} \\
(<29 \mu \mathrm{g} / \mathrm{mL}) \text { for } 4 \text { and } 7 \text { days }\end{array}$ & [12] \\
\hline $\begin{array}{l}\text { Aqueous precipitation at } \\
60^{\circ} \mathrm{C} \text { and heat treatment } \\
\text { at } 600^{\circ} \mathrm{C}\end{array}$ & $23^{\wedge} \pm^{\wedge} 7.89 \mathrm{~nm}$ & 0 to $100 \mu \mathrm{g} / \mathrm{mL}$ & in vitro, & $\begin{array}{l}\text { Neuro2A (murine } \\
\text { neuroblastoma cells) }\end{array}$ & Exposure to $\mathrm{CeO}_{2}$ & $\begin{array}{l}\text { Concentration-dependent cytotoxicity. } \mathrm{EC}_{20}\left(\mathrm{MTT}_{\text {assay }} \mathrm{y}^{(ब)}\right) \text { : } \\
\text { between } 3.1 \text { and } 6.25 \mu \mathrm{g} / \mathrm{mL} \text { for } 24 \mathrm{~h}\end{array}$ & [s6] \\
\hline $\begin{array}{l}\text { Supercritical synthesis } \\
\text { (temperature not } \\
\text { mentioned) }\end{array}$ & ca. $130 \mathrm{~nm}$ & $\begin{array}{l}50,100,200 \text {, and } 400 \mathrm{mg} / \mathrm{kg}(290- \\
2325 \mu \mathrm{mol} / \mathrm{kg})\end{array}$ & in vivo & ICR male mice & $\begin{array}{l}\text { Intratracheal } \\
\text { instillation }\end{array}$ & Inflammatory responses and delayed-type hypersensitivity & {$[57 \mid$} \\
\hline Precipitation at r.t. & $5 \mathrm{~nm}$ & $40 \mathrm{mg} / \mathrm{mL}$ or $85 \mathrm{mg} / \mathrm{kg}$ & in vivo & Rats & Vascular infusion & Hepatic injury and oxidative stress & [26] \\
\hline $\begin{array}{l}\text { Hydrothermal method } \\
\left(80^{\circ} \mathrm{C}\right)\end{array}$ & $5 \mathrm{~nm}$ & $(0$ or $85 \mathrm{mg} / \mathrm{kg}) 495 \mu \mathrm{mol} / \mathrm{kg}$ & in vivo & Rats & Intravenous infusion $\mathrm{F}$ & Pro-oxidant effects on the brain even without crossing BBB & [25] \\
\hline $\begin{array}{l}\text { Hydrothermal method } \\
\left(180^{\circ} \mathrm{C}\right)\end{array}$ & $31.2^{\wedge} \pm^{\wedge} 17.1 \mathrm{~nm}$ & $70 \mathrm{mg} / \mathrm{kg}(495 \mu \mathrm{M} / \mathrm{kg})$ & in vivo & $\begin{array}{l}\text { Male Sprague Dawley }, \\
\text { rats }\end{array}$ & Intravenous infusion ${ }_{\mathrm{g}}^{7}$ & $\begin{array}{l}\text { Time-dependent oxidative stress in spleen and liver and hepatic } \\
\text { granuloma }\end{array}$ & {$[38]$} \\
\hline $\begin{array}{l}\text { Surfactant-assisted } \\
\text { hydrothermal method at } \\
180^{\circ} \mathrm{C}\end{array}$ & $\begin{array}{l}3-5 \mathrm{~nm} \text { (agglomerate } \\
\text { size: } \\
\left.1731^{\wedge} \pm 165 \mathrm{~nm}\right)\end{array}$ & $40 \mu \mathrm{g}$ & in vivo & Male CD-1 mice & $\begin{array}{l}\text { Intratracheal } \\
\text { instillation }\end{array}$ & $\begin{array}{l}\text { Oxidative stress, inflammatory responses, cytotoxicity. BAL } \\
\text { inflammation and cytotoxicity in early stage, redox activity-evoked } \\
\text { lipid peroxidation }\end{array}$ & [4] \\
\hline Precipitation at r.t. & $\begin{array}{l}3-5 \mathrm{~nm} \text { (agglomerate } \\
\left.\text { size: } 313^{\wedge} \pm^{\wedge} 30 \mathrm{~nm}\right)\end{array}$ & $40 \mu \mathrm{g}$ & in vivo & Male CD-1 mice & $\begin{array}{l}\text { Intratracheal } \\
\text { instillation }\end{array}$ & Oxidative stress, acute inflammatory responses, cytotoxicity. & |44] \\
\hline Preparation method & Size & $\mathrm{C}$ & Test & Host & d 1 & Eff & Ref. \\
\hline \multicolumn{8}{|l|}{ No significant effects } \\
\hline Flame spray synthesis & $35-40 \mathrm{~nm}$ & $0.001-50 \mu \mathrm{g} / \mathrm{mL}$ & in vitro & $\begin{array}{l}\text { HAECs (human aortic } \\
\text { endothelial cells) }\end{array}$ & Exposure to $\mathrm{CeO}_{2}$ & Very little inflammatory response; nontoxic & [58] \\
\hline $\begin{array}{l}\text { Thermohydrolysis at high } \\
\text { temperature }\end{array}$ & $7.0^{\circ} \pm 0.15 \mathrm{~nm}$ & $10 \mu \mathrm{M}$ to $50 \mathrm{mM}$ & in vitro & $\begin{array}{l}\mathrm{NIH} / 3 \mathrm{~T} 3 \text { (fibroblast cells } \\
\text { from mice) }\end{array}$ & ${ }^{\mathrm{s}}$ Exposure to $\mathrm{CeO}_{2}$ & $\begin{array}{l}\text { Good biocompatibility. } \mathrm{EC}_{20} \text { (MTT assay }{ }^{\left({ }^{(j)}\right)}: 260 \mu \mathrm{g} / \mathrm{cm}^{2} \\
(0.52 \mu \mathrm{g} / \mathrm{L} \text { or } 3 \mathrm{mM}) \text { for } 24 \mathrm{~h}\end{array}$ & |59| \\
\hline $\begin{array}{l}\text { Homogeneous nucleation } \\
\text { at } 50^{\circ} \mathrm{C} \text { and drying at } \\
60^{\circ} \mathrm{C}\end{array}$ & $\begin{array}{l}8^{\wedge} \pm^{\wedge} 2 \text { and } \\
35^{\wedge} \pm^{\wedge} 10 \mathrm{~nm} \\
\text { (agglomerates size: } \\
74^{\wedge} \pm^{\wedge} 2 \text { and } \\
163^{\wedge} \pm^{\wedge} 59 \mathrm{~nm} \text {, } \\
\text { respectively) }\end{array}$ & $10 \mathrm{fg} / \mathrm{mL}$ to $100 \mu \mathrm{g} / \mathrm{mL}$ & in vitro & $\begin{array}{l}\text { Immortalized human } \\
\text { microvascular (HMEC- } \\
\text { 1) and primary } \\
\text { macrovascular } \\
\text { endothelial cells } \\
\text { (HUVEC) }\end{array}$ & Exposure to $\mathrm{CeO}_{2}$ & \multicolumn{2}{|l|}{$\begin{array}{l}\text { Slight cytotoxic effects observed, but the expected impact in vivo is }|4| \\
\text { considered low. }\end{array}$} \\
\hline Microemulsion at r.t. & $3-5 \mathrm{~nm}$ & $10 \mathrm{nM}(0.0017 \mu \mathrm{L})$ & in vitro & $\begin{array}{l}\text { MCF-7 (human breast } \\
\text { tumor cell line) }\end{array}$ & $\begin{array}{l}\text { Irradiation of cells in, } \\
\text { presence of } \\
\text { nanoceria }\end{array}$ & $\begin{array}{l}\text { No radioprotection against tumor cells. EC } 20 \text { (MTT assay }{ }^{\left({ }^{(d)}\right)}: 8.6 \\
\mathrm{ng} / \mathrm{mL} \text { for } 24 \mathrm{~h}\end{array}$ & [19! \\
\hline $\begin{array}{l}\text { Aqueous precipitation at } \\
40^{\circ} \mathrm{C} \text { and heat treatment } \\
\text { at } 600^{\circ} \mathrm{C}\end{array}$ & $20-40 \mathrm{~nm}$ & 0 to $125 \mu \mathrm{g} / \mathrm{mL}$ & in vitro & $\begin{array}{l}\text { neuro2 A (murine } \\
\text { neuroblastoma cells) }\end{array}$ & Exposure to $\mathrm{CeO}_{2}$ & $\begin{array}{l}\text { Very low cytotoxic effect. } \mathrm{EC}_{20}\left(\mathrm{MTT} \text { assay } \mathrm{y}^{(\mathrm{d})}\right): \text { between } 7.81 \text { and } \\
15.6 \mathrm{\mu g} / \mathrm{mL} \text { for } 24 \mathrm{~h}\end{array}$ & [60\} \\
\hline $\begin{array}{l}\text { Simple wet chemistry at } \\
\text { r.t. }\end{array}$ & $\begin{array}{l}3-5 \mathrm{~nm} \text { (agglomerate } \\
\text { size: } 10-50 \mathrm{~nm})\end{array}$ & $\begin{array}{l}0.1 \mathrm{mg} / \mathrm{kg} \text { to } 0.5 \mathrm{mg} / \mathrm{kg} \text { once or } \\
\text { twice after } 15 \mathrm{~d}\end{array}$ & in vivo & C57BL/6 mice & $\begin{array}{l}\text { Injected } \\
\text { intravenously }\end{array}$ & $\begin{array}{l}\mathrm{CeO}_{2} \text { accumulation at the site of injection, in liver and in kidneys, } \\
\text { but no pathogenic side effects observed }\end{array}$ & [61] \\
\hline $\begin{array}{l}\text { Hydrothermal method at } \\
80^{\circ} \mathrm{C}\end{array}$ & $4-6 \mathrm{~nm}$ & 100,175 , and $250 \mathrm{mg} / \mathrm{kg}$ & in vivo & Sprague-Dawley rats & Intravenous infus & $\begin{array}{l}\text { No neurotoxicity effects, no BBB crossing, no pro- or anti-oxidative, } \\
\text { effect in the brain }\end{array}$ & $\mathbf{e}_{[62]}$ \\
\hline $\begin{array}{l}\text { Simple wet chemistry at } \\
\text { r.t. }\end{array}$ & $\begin{array}{l}3-5 \mathrm{~nm} \text { (agglomerate } \\
\text { size: } \geq 50 \mathrm{~nm} \text { in cells) }\end{array}$ & $\begin{array}{l}\text { Five doses (one dose a week) of } \\
0.5 \mathrm{mg} / \mathrm{kg} \text { body weight suspended } \\
\text { in } 100 \mu \mathrm{L} \text { of sterile saline }\end{array}$ & in vivo & $\mathrm{CD}-1$ mice & $\begin{array}{l}\text { Intravenous } \\
\text { administration }\end{array}$ & Non-toxic accumulation in the skin & [63] \\
\hline $\begin{array}{l}\text { Precipitation method and } \\
\text { treatment in bomb at } \\
100^{\circ} \mathrm{C}\end{array}$ & $\begin{array}{l}4.6 \text { and } 31.2 \mathrm{~nm} \\
\text { cubic nanoceria and } \\
9.9 \pm^{\wedge} 2.0^{\wedge} \times^{\wedge} 264^{\wedge} \pm^{\wedge} \\
112 \mathrm{~nm} \text { nanorods }\end{array}$ & $\begin{array}{l}11-55 \mathrm{mg} / \mathrm{kg}(5 \mathrm{~nm}) \text { over } 5 \mathrm{~d}, \\
6 \mathrm{mg} / \mathrm{kg}(30 \mathrm{~nm}), 20-50 \mathrm{mg} / \mathrm{kg} \\
\text { (nanorods) }\end{array}$ & in vivo & $\begin{array}{l}\text { Male Sprague Dawley } \\
\text { rats }\end{array}$ & $\begin{array}{l}\text { Intravenous } \\
\text { administration }\end{array}$ & $\begin{array}{l}\text { Lack of significant toxicity for nanorods with lengths below } \\
500 \mathrm{~nm} \text {. Ceria nanorods were not significantly more toxic than } \\
\text { cubic/polyhedral nanoceria. }\end{array}$ & 1641 \\
\hline $\begin{array}{l}\text { Hydrothermal method at } \\
240^{\circ} \mathrm{C}\end{array}$ & $\begin{array}{l}\text { 4-6 nm (agglomerate } \\
\left.\text { size: } 191 \backsim \pm^{\wedge} 77 \mathrm{~nm}\right)\end{array}$ & $\begin{array}{l}0,10,50,100,200 \text {, and } 400 \mu \mathrm{g} \mathrm{pe} \\
300 \mu \mathrm{L}\end{array}$ & in vivo & $\begin{array}{l}\text { Male Sprague-Dawley } \\
\text { rats }\end{array}$ & $\begin{array}{l}\text { Intratracheally } \\
\text { instilled }\end{array}$ & $\begin{array}{l}\text { Detrimental effects on local blood flow regulation and } \\
\text { cardiovascular dysfunction. EC } \text { so }_{0} \text { range from } 15 \text { to } 100 \mu \mathrm{g} \text { per } \\
300 \mu \mathrm{L}\end{array}$ & 1051 \\
\hline
\end{tabular}


Table 1. (Continued).

\begin{tabular}{|c|c|c|c|c|c|c|c|}
\hline Preparation method & Size & Concentration & Test & Host & Exposure method & Effect & Ref. \\
\hline \multicolumn{8}{|l|}{ Protective effects } \\
\hline Microemulsion at r.t. & $3-5 \mathrm{~nm}$ & $10 \mathrm{nM}(0.0017 \mu \mathrm{g} / \mathrm{mL})$ & in vitro & $\begin{array}{l}\text { CRL } 8798 \text { (immortalized I } \\
\text { normal breast epithelial } \\
\text { cells) }\end{array}$ & $\begin{array}{l}\text { Irradiation of cells in } \\
\text { presence of } \\
\text { nanoceria }\end{array}$ & $\begin{array}{l}{ }^{\mathrm{n}} \text { Enhanced cell survival and radioprotection. } \mathrm{EC}_{20} \text { (MTT assay }{ }^{\left({ }^{|d|}\right)} \text { ): } \\
>0.86 \mu \mathrm{g} / \mathrm{mL} \text { for } 24 \mathrm{~h}\end{array}$ & [19] \\
\hline Microemulsion at r.t. & $3-5 \mathrm{~nm}$ & $10 \mathrm{nM}(0.0017 \mu \mathrm{g} / \mathrm{mL})$ & in vitro & $\begin{array}{l}\text { CCL } 135 \text { (normal lung } \\
\text { fibroblast) }\end{array}$ & $\begin{array}{l}\text { Irradiation of cells in } \\
\text { presence of } \\
\text { nanoceria }\end{array}$ & Radioprotection. $\mathrm{EC}_{20}$ (MTT assay $\left.{ }^{(d)}\right):>0.86 \mu \mathrm{g} / \mathrm{mL}$ for $24 \mathrm{~h}$ & 166] \\
\hline Precipitation $\left(70^{\circ} \mathrm{C}\right)$ & $5-8 \mathrm{~nm}$ & 59 to $290 \mu \mathrm{M}(0,25$, or $50 \mu \mathrm{g} / \mathrm{mL})$ & in vitro & $\begin{array}{l}\text { Mouse-derived cardiac } \\
\text { progenitor cells }\end{array}$ & $\begin{array}{l}\text { Exposure to } \mathrm{H}_{2} \mathrm{O}_{2} \\
\text { following exposure } \\
\text { to } \mathrm{CeO}_{2}\end{array}$ & Anti-oxidative protection & $167 \mid$ \\
\hline $\begin{array}{l}\text { Simple wet chemistry at } \\
\text { r.t. }\end{array}$ & $\begin{array}{l}\text { 3-5 nm (agglomerate } \\
\text { size: } 10-50 \mathrm{~nm})\end{array}$ & $10 \mu \mathrm{M}$ & in vitro & $\begin{array}{l}\text { ATCC (murine J774A.1 } \\
\text { macrophage cell line) }\end{array}$ & Exposure to $\mathrm{CeO}_{2}$ & $\begin{array}{l}\text { No toxic effect; ROS quenching; reduction of free radical NO } \\
\text { production }\end{array}$ & [6]] \\
\hline $\begin{array}{l}\text { Wet chemistry at } 150^{\circ} \mathrm{C} \text {, } \\
\text { calcination at } 200^{\circ} \mathrm{C}\end{array}$ & $3-8 \mathrm{~nm}$ & 1,10 , or $100 \mathrm{nM}$ & in vitro & $\begin{array}{l}\text { CRL-1446 ( } \mathrm{H} 9 \mathrm{c} 2 \text { rat } \\
\text { heart-derived embryonic } \\
\text { myocytes) }\end{array}$ & Exposure to $\mathrm{CeO}_{2}$ & $\begin{array}{l}\text { Increase viability; inhibition of ROS, inflammation and cigarette } \\
\text { smoke extract-induced cell damage }\end{array}$ & $\{23,24$ \\
\hline Wet chemistry at r.t. & 6 and $12 \mathrm{~nm}$ & 1 to $120 \mu \mathrm{M}$ & in vitro & HT22 (nerve cells) & Exposure to $\mathrm{CeO}_{2}$ & Protection against oxidative stress & 1301 \\
\hline Microemulsion at r.t. & $3-5 \mathrm{~nm}$ & $10 \mathrm{~nm}$ & in vitro & $\begin{array}{l}\text { Rat spinal cord neurons } \\
\text { Cardiomyocytes }(\mathrm{H} 9 \mathrm{c} 2) \text {, }\end{array}$ & Exposure to $\mathrm{CeO}_{2}$ & Protection against oxidative stress $\left(\mathrm{H}_{2} \mathrm{O}_{2}\right)$ & 1081 \\
\hline Precipitation at r.t. & $\begin{array}{l}4 \mathrm{~nm} \text { (agglomerate } \\
\text { size: } 10 \mathrm{~nm})\end{array}$ & $1.0 \mathrm{~mm}$ & in vitro & $\begin{array}{l}\text { human dermal } \\
\text { fibroblasts (BJ), lung } \\
\text { cancer (A549) and breast } \\
\text { cancer cells (BT-474) }\end{array}$ & Exposure to $\mathrm{CeO}_{2}$ & $\begin{array}{l}\text { Antioxidative protection for normal cells, but not to cancer cells } \\
\text { when exposed to } \mathrm{H}_{2} \mathrm{O}_{2} \text {. No difference in cell viability when exposed } \\
\text { to nanoceria alone at a concentration of } 0.17 \mathrm{mg} / \mathrm{mL} \text { (1.0 mM) }\end{array}$ & $a^{|4|]}$ \\
\hline $\begin{array}{l}\text { Simple wet chemistry at } \\
\text { r.t. }\end{array}$ & $\begin{array}{l}3-5 \mathrm{~nm} \text { (agglomerate } \\
\text { size } \geq 50 \mathrm{~nm} \text { in cells) }\end{array}$ & $150 \mu \mathrm{m}$ & in vitro & $\begin{array}{l}\text { Human dermal } \\
\text { fibroblasts and squamous, } \\
\text { carcinoma cell line SCL- } \\
1\end{array}$ & Exposure to $\mathrm{CeO}_{2}$ & $\begin{array}{l}\text { Nontoxic to normal cells but cytotoxic for cancerous cells, leading } \\
\text { to the inhibition of tumor invasion. } \mathrm{EC}_{20} \text { (MTT assay } \\
>51.6 \mu \mathrm{g} / \mathrm{mL} \text { ( } 300 \mu \mathrm{M}) \text { for normal cells and } 17.2 \mu \mathrm{gLL}(100 \mu \mathrm{M}) \\
\text { for cancer cells for } 48 \mathrm{~h}\end{array}$ & [61] \\
\hline $\begin{array}{l}\text { Precipitation at r.t. in } \\
\text { presence of PEG }\end{array}$ & $3-5 \mathrm{~nm}$ & $10,50,100,500 \mu \mathrm{M}$ & in vitro & $\begin{array}{l}\text { Normal human } \\
\text { keratinocyte (HaCat) } \\
\text { cells }\end{array}$ & Exposure to $\mathrm{CeO}_{2}$ & $\begin{array}{l}\text { Good cell viability; quenching of peroxide and superoxide radicals. } \\
\mathrm{EC}_{20}(\mathrm{MTT} \text { assay } \\
86.1 \mu \mathrm{g} / \mathrm{mL}(500 \mu \mathrm{M}) \text { forween } 17.2 \mu \mathrm{g} / \mathrm{mL}(100 \mu \mathrm{M}) \text { and } \\
\end{array}$ & $\mid 69]$ \\
\hline $\begin{array}{l}\text { Precipitation at r.t. } \\
\text { sintered at } 800^{\circ} \mathrm{C}\end{array}$ & $\begin{array}{l}3-5 \mathrm{~nm}(\text { agglomerate } \\
\text { size: } 5-15 \mathrm{~nm})\end{array}$ & Incorporated in bioactive glass & in vitro & $\begin{array}{l}\text { Human mesenchymal } \\
\text { stem cells }\end{array}$ & $\begin{array}{l}\text { Allowing cell } \\
\text { growth on ceria } \\
\text { substrate }\end{array}$ & $\begin{array}{l}\text { Nontoxic according to LIVE/DEAD assay; enhanced osteoblastic } \\
\text { differentiation and collagen production }\end{array}$ & 1901 \\
\hline $\begin{array}{l}\text { Precipitation method, } \\
\text { calcination at } 800^{\circ} \mathrm{C}\end{array}$ & $6-16 \mathrm{~nm}$ & $600 \mathrm{mM}(100 \mu \mathrm{g} / \mathrm{mL})$ & in vitro & $\begin{array}{l}\text { SH-SY5Y } \\
\text { (neuroblastoma cell line) }\end{array}$ & Exposure to $\mathrm{CeO}_{2}$ & Protection against oxidative stress & 1919 \\
\hline $\begin{array}{l}\text { Flame spray pyrolysis } \\
\left(1927-2327^{\circ} \mathrm{C}\right)\end{array}$ & $\begin{array}{l}8 \mathrm{~nm} \text { (agglomerate } \\
\text { size: } 2610 \mathrm{~nm} \text { in } \\
\text { water and } 323 \mathrm{~nm} \text { in } \\
\text { DMEM }^{(5])}\end{array}$ & $10 \mathrm{mg} / \mathrm{mL}$ & in vitro & $\begin{array}{l}\text { RAW } 264.7 \text { cells and } \\
\text { BEAS- } 2 \text { B cells }\end{array}$ & Exposure to $\mathrm{CeO}_{2}$ & $\begin{array}{l}\text { No cytotoxicity (MTS assay }{ }^{(e)} \text { ) and no inflammation observed for } \\
25 \mu \mathrm{g} / \mathrm{mL} \text { for up to } 16 \mathrm{~h} \text {; reduced ROS production; and increased } \\
\text { resistance against oxidative stress }\end{array}$ & [72] \\
\hline Wet chemistry at r.t. & 6 and $12 \mathrm{~nm}$ & $20 \mu \mathrm{g} / \mathrm{mL}$ & in vitro & HT22 (nerve cells) & Exposure to $\mathrm{CeO} 2$ & $\begin{array}{l}\text { Protection against oxidative stress. No difference in cell viability } \\
\text { (MTT assay } y^{d(d)} \text { ) for up to } 80 \mu \mathrm{gL} \text { for } 20 \mathrm{~h}\end{array}$ & 1301 \\
\hline Wet chemistry at r.t. & $\begin{array}{l}3-5 \mathrm{~nm} \text { (agglomerate } \\
\text { size }<10 \mathrm{~nm})\end{array}$ & $1 \mu \mathrm{L}$ of $1 \mathrm{mM}(172 \mathrm{ng})$ per eye & in vivo & $\begin{array}{l}\text { Knockout mice that } \\
\text { develops intra-retinal } \\
\text { and sub-retinal } \\
\text { neovascular lesions }\end{array}$ & Intravitreal injection & $\begin{array}{l}\text { Inhibition of ROS production; inhibition of formation and } \\
\text { regression of lesions }\end{array}$ & [3] \\
\hline Microemulsion at r.t. & $3-5 \mathrm{~nm}$ & $\begin{array}{l}0.06 \mathrm{nmol} / \mathrm{kg} \text { ( } 6 \text { times within } 2 \\
\text { weeks) }\end{array}$ & in vivo & Athymic nude mice & $\begin{array}{l}\text { Injection before } \\
\text { irradiation }\end{array}$ & Radioprotection & 166] \\
\hline
\end{tabular}

[a] r.t.: room temperature. [b] SRB: sulforhodamine B. ${ }^{[74]}$ [c] LDH: lactate dehydrogenase. ${ }^{[75]}$ [d] MTT assay: 3-(4,5-dimethylthiazol-2-yl)2,5-diphenyltetrazolium bromide (or tetrazolium salt) assay. ${ }^{[76]}$ [e] DMEM: Dulbecco's modified Eagle's medium. [f] WST-1: water soluble tetrazolium salts [or 2-(4-iodophenyl)-3-(4-nitrophenyl)-5-(2,4-disulfophenyl)- $2 H$-tetrazolium, also called cell proliferation reagent]. ${ }^{[77]}[\mathrm{g}]$ MTS: 3-(4,5-dimethylthiazol-2-yl)-5-(3-carboxymethoxyphenyl)-2-(4-sulfophenyl)-2 $H$-tetrazolium. ${ }^{[78]}$

fects in spite of its cytotoxic behavior. On the other hand, we observed that protective effects are more commonly, but not always, found for small NPs (smaller than $20 \mathrm{~nm}$ ), whereas no size dependence is observed for the adverse effects. In fact, among the 31 nanoceria with diameters smaller than $20 \mathrm{~nm}, 7(22 \%)$ had adverse effects, 8 (26\%) had little effect, and $16(52 \%)$ had protective effects. For the 13 nanoceria materials with diameters larger than $20 \mathrm{~nm}$, including the material found to have both adverse and protective effects, $9(69 \%)$ had adverse effects, $4(31 \%)$ had little effect, and $1(8 \%)$ had protective effects. Finally, cancer-derived cells tend to be more sensitive to the presence of nanoceria. When a cancerous cell line was used (10 tests), $5(50 \%)$ tests resulted in adverse effects, $1(10 \%)$ in little effect, and $4(40 \%)$ in protective effects. When a normal cell line was used (35 tests), 11 (31\%) resulted in adverse effects, $9(26 \%)$ in little effect, and $15(43 \%)$ in protective effects. As already demonstrated by Perez et al., ${ }^{[41]}$ nanoceria tend to offer less antioxidative protection to cancerous cells than to normal cells, hence there seems to be a potential for the application of nanoceria in cancer therapy.

Interpreting and comparing toxicity results often represents a challenge. Results can easily be misinterpreted. As an example, we have recently presented results on ceria nanocontainers with and without silver content. ${ }^{[12]}$ We observed that, while using the lactate dehydrogenase (LDH) assay, the ceria nanocontainers did not show any cytotoxicity effect. On the other hand, when we observed A549 cells with a confocal laser scanning microscope, we saw the shrinkage of cell sizes and membranes, which are typical signs of apoptosis. It is therefore important to use more than one technique to determine whether a material really has a toxic effect. In addition, in our experimental setup, we allowed cells to grow directly on ceria nanocontainers, which provides a very rough surface for cells and probably increases apoptosis. Since in the final application, these ceria nanocontainers are to be embedded in a biomaterial coating, the exposure method is not fully representative of this application. Comparing the cytotoxicity results for free nanoceria with those for nanoceria embedded in a biocompatible matrix could enable a better evaluation of the biosafety of this material. ${ }^{[12]}$

In order to fully assess the toxicology and biological activity of ceria materials, a complete characterization of the material, that is its NP size, agglomerate size, zeta potential, surface properties and porosity, should be included in the 
toxicity study. It is also very likely that the oxygen vacancies play an important role as they confer redox-properties upon nanomaterials. However, to determine these vacancies, physical analytical tools need to be used, which are often less available in the bio-oriented laboratories. In addition, a full characterization of the test conditions ( $\mathrm{pH}$ of culture medium, $\mathrm{pH}$ variation, salt concentration, etc.) would also be essential for in vitro tests, as these properties can affect the surface properties and stability of materials. ${ }^{[32,34]}$ When possible, a characterization of the nanoceria recovered after in vitro or in vivo experiments could be valuable in order to understand the effects of nanoceria on biological systems and the variations in toxicity and biological activities.

Finally, as it has already been pointed out by Kumar et al., ${ }^{[32]}$ a better collaboration between research groups of different fields could be very beneficial in building a detailed database on ceria toxicity. This would be especially useful when two groups observed different effects for similar nanoceria materials in order to determine the cause(s) of these differences.

\section{Conclusions}

Toxicity results for ceria often seem contradictory, and a unique reliable toxicity assessment for ceria is still missing. ${ }^{[1,11]}$ In addition, as mentioned above, ceria toxicity tests are greatly dependent on synthesis conditions, physical and chemical properties, surface properties, cell type, exposition method, and various other characteristics. The use of a coating has also a considerable impact on nanoceria toxicity in such a way that its toxicity can be reduced by using a coating that prevents aggregation and precipitation. ${ }^{[79]}$ All these variables make the comparability between the different ceria materials very difficult to achieve and thus ceria toxicity difficult to assess. ${ }^{[3]}$ For this reason, it is a good idea to perform toxicity tests for the newly developed materials under conditions that mimic the most likely potential organism exposure. As long as a detailed database for ceriabased materials is not developed, it is essential to test all newly developed ceria materials designated for biomedical applications in vitro and in vivo by using an experimental setup as representative of the final application as possible. We hope that this review will help other researchers to design their experimental setups and to make the right choice of nanoceria materials for the desired functions. Despite all the conflicting evidence on ceria toxicity, this material has very promising applications in areas such as drug delivery systems, ${ }^{[12]}$ neurodegenerative disease therapy, ${ }^{[80]}$ medical imaging, ${ }^{[81]}$ and cancer treatment. ${ }^{[1,82]}$

\section{Acknowledgments}

The authors are grateful to the Swiss National Science Foundation (NRP-62), the University of Fribourg, and the Fribourg Center for Nanomaterials for their financial support.

[1] M. S. Wason, J. Zhao, Am. J. Transl. Res. 2013, 5, 126-131.
[2] S. Eckhardt, P. S. Brunetto, J. Gagnon, M. Priebe, B. Giese, K. M. Fromm, Chem. Rev. 2013, 113, 4708-4754; C. Mühlfeld, B. Rothen-Rutishauser, F. Blank, D. Vanhecke, M. Ochs, P. Gehr, Am. J. Physiol. - Lung C 2008, 294, L817-L829.

[3] R. Landsiedel, U. G. Sauer, L. Ma-Hock, J. Schnekenburger, M. Wiemann, Nanomedicine 2014, 9, 2557-2585.

[4] C. Strobel, M. Förster, I. Hilger, Beilstein J. Nanotechnol. 2014, 5, 1795-1807.

[5] M. Fisichella, F. Berenguer, G. Steinmetz, M. Auffan, J. Rose, O. Prat, BMC Genomics 2014, 15, 700-715.

[6] R. A. Yokel, S. Hussain, S. Garantziotis, P. Demokritou, V. Castranova, F. R. Cassee, Environ. Sci.: Nano 2014, 1, 406-428.

[7] K. Reed, A. Cormack, A. Kulkarni, M. Mayton, D. Sayle, F. Klaessig, B. Stadler, Environ. Sci.: Nano 2014, 1, 390-405.

[8] M. Melchionna, P. Fornasiero, Mater. Today 2014, 17, 349357.

[9] G. Vlaic, R. Di Monte, P. Fornasiero, E. Fonda, J. Kašpar, M. Graziani, J. Catal. 1998, 182, 378-389.

[10] S. Steiner, L. Mueller, O. B. Popovicheva, D. O. Raemy, J. Czerwinski, P. Comte, A. Mayer, P. Gehr, B. Rothen-Rutishauser, M. J. D. Clift, Toxicol. Lett. 2012, 214, 218-225.

[11] F. R. Cassee, E. C. van Balen, C. Singh, D. Green, H. Muijser, J. Weinstein, K. Dreher, Crit. Rev. Toxicol. 2011, 41, 213-229.

[12] J. Gagnon, M. J. D. Clift, D. Vanhecke, D. A. Kuhn, P. Weber, A. Petri-Fink, B. Rothen-Rutishauser, K. M. Fromm, J. Mater. Chem. B 2015, 3, 1760-1768.

[13] R. A. Yokel, M. T. Tseng, M. Dan, J. M. Unrine, U. M. Graham, P. Wu, E. A. Grulke, Nanomed-Nanotechnol. 2013, 9, 398-407.

[14] A. S. Karakoti, P. Munusamy, K. Hostetler, V. Kodali, S. Kuchibhatla, G. Orr, J. G. Pounds, J. G. Teeguarden, B. D. Thrall, D. R. Baer, Surf. Interface Anal. 2012, 44, 882-889.

[15] J. Kašpar, P. Fornasiero, M. Graziani, Catal. Today 1999, 50, 285-298.

[16] E. Shoko, M. F. Smith, R. H. McKenzie, J. Phys. Condens. Matter 2010, 22, 223201.

[17] F. Esch, S. Fabris, L. Zhou, T. Montini, C. Africh, P. Fornasiero, G. Comelli, R. Rosei, Science 2005, 309, 752-755.

[18] J. M. Dowding, T. Dosani, A. Kumar, S. Seal, W. Self, Chem. Commun. 2012, 48, 4896-4898.

[19] R. W. Tarnuzzer, J. Colon, S. Patil, S. Seal, Nano Lett. 2005, 5 , 2573-2577.

[20] Y.-W. Zhang, R. Si, C.-S. Liao, C.-H. Yan, C.-X. Xiao, Y. Kou, J. Phys. Chem. B 2003, 107, 10159-10167; A. Saadat-Monfared, M. Mohseni, M. H. Tabatabaei, Colloids Surf. A 2012, $408,64-70$.

[21] A. Hosseini, A. M. Sharifi, M. Abdollahi, R. Najafi, M. Baeeri, S. Rayegan, J. Cheshmehnour, S. Hassani, Z. Bayrami, M. Safa, Biol. Trace Elem. Res. 2015, 164, 80-89; A. B. Shcherbakov, N. M. Zholobak, V. K. Ivanov, O. S. Ivanova, A. V. Marchevsky, A. E. Baranchikov, N. Y. Spivak, Y. D. Tretyakov, Russ. J. Inorg. Chem. 2012, 1411-1418; A. Y. Estevez, S. Pritchard, K. Harper, J. Aston, A. Lynch, J. J. Lucky, J. S. Ludington, P. Chatani, W. P. Mosenthal, J. C. Leiter, S. Andreescu, J. S. Erlichman, Free Radical Biol. Med. 2011, 51, 1155-1163; A. Karakoti, S. Singh, J. M. Dowding, S. Seal, W. T. Self, Chem. Soc. Rev. 2010, 39, 4422-4432.

[22] L. De Marzi, A. Monaco, J. De Lapuente, D. Ramos, M. Borras, M. Di Gioacchino, S. Santucci, A. Poma, Int. J. Mol. Sci. 2013, 14, 3065-3077.

[23] J. Niu, K. Wang, P. E. Kolattukudy, J. Pharm. Exp. Ther. 2011, $338,53-61$.

[24] C. Korsvik, S. Patil, S. Seal, W. T. Self, Chem. Commun. 2007, 1056-1058.

[25] S. S. Hardas, R. Sultana, G. Warrier, M. Dan, R. L. Florence, P. Wu, E. A. Grulke, M. T. Tseng, J. M. Unrine, U. M. Graham, R. A. Yokel, D. A. Butterfield, Neurotoxicology 2012, 33, $1147-1155$. 
[26] M. T. Tseng, X. Lu, X. Duan, S. S. Hardas, R. Sultana, P. Wu, J. M. Unrine, U. M. Graham, D. A. Butterfield, E. A. Grulke, R. A. Yokel, Toxicol. Appl. Pharmacol. 2012, 260, 173-182.

[27] A. Briggs, S. Corde, S. Oktaria, R. Brown, A. Rosenfeld, M Lerch, K. Konstantinov, M. Tehei, Nanomed. Nanotechnol. Biol. Med. 2013, 9, 1098-1105.

[28] A. Nemmar, J. A. Holme, I. Rosas, P. E. Schwarze, E. AlfaroMoreno, Biomed. Res. Int. 2013, Article ID 279371.

[29] G. Oberdörster, E. Oberdörster, J. Oberdörster, Environ. Health Perspect. 2005, 113, 823-839.

[30] D. Schubert, R. Dargusch, J. Raitano, S.-W. Chan, Biochem. Biophys. Res. Commun. 2006, 342, 86-91.

[31] I. Gosens, L. E. A. M. Mathijssen, B. G. H. Bokkers, H. Muijser, F. R. Cassee, Nanotoxicology 2014, 8, 643-653.

[32] A. Kumar, S. Das, P. Munusamy, W. Self, D. R. Baer, D. C. Sayle, S. Seal, Environ. Sci.: Nano 2014, 1, 516-532.

[33] B. Fubini, M. Ghiazza, I. Fenoglio, Nanotoxicology 2010, 4, 347-363; V. Kasturirangan, B. M. Nair, M. T. S. Kariapper W. G. Lesniak, W. Tan, R. Bizimungu, P. Kanter, K. Toth, S. Buitrago, Y. M. Rustum, A. Hutson, L. P. Balogh, M. K. Khan, Nanotoxicology 2013, 7, 441-451.

[34] S. Patil, A. Sandberg, E. Heckert, W. Self, S. Seal, Biomaterials 2007, 28, 4600-4607.

[35] R. K. Singh, T.-H. Kim, K. D. Patel, J. C. Knowles, H.-W. Kim, J. Biomed. Mater. Res. A 2012, 100, 1734-1742.

[36] B. K. Gaiser, T. F. Fernandes, M. A. Jepson, J. R. Lead, C. R. Tyler, M. Baalousha, A. Biswas, G. J. Britton, P. A. Cole, B. D. Johnston, Y. Ju-Nam, P. Rosenkranz, T. M. Scown, V. Stone, Environ. Toxicol. Chem. 2012, 31, 144-154.

[37] B. M. Rotoli, O. Bussolati, A. L. Costa, M. Blosi, L. Cristo, P. P. Zanello, M. G. Bianchi, R. Visigalli, E. Bergamaschi, $J$. Nanopart. Res. 2012, 14, 1069.

[38] R. A. Yokel, T. C. Au, R. MacPhail, S. S. Hardas, D. A. Butterfield, R. Sultana, M. Goodman, M. T. Tseng, M. Dan, H. Haghnazar, J. M. Unrine, U. M. Graham, P. Wu, E. A. Grulke, Toxicol. Sci. 2012, 127, 256-268.

[39] E.-J. Park, J. Choi, Y.-K. Park, K. Park, Toxicology 2008, 245, 90-100.

[40] H. Zhang, X. He, Z. Zhang, P. Zhang, Y. Li, Y. Ma, Y. Kuang, Y. Zhao, Z. Chai, Environ. Sci. Technol. 2011, 45, 3725-3730; S. K. Nalabotu, M. B. Kolli, W. E. Triest, J. Y. Ma, N. D. P. K. Manne, A. Katta, H. S. Addagarla, K. M. Rice, E. R. Blough, Int. J. Nanomed. 2011, 2327-2335.

[41] J. M. Perez, A. Asati, S. Nath, C. Kaittanis, Small 2008, 4, 552 556

[42] W. Lin, Y.-w. Huang, X.-D. Zhou, Y. Ma, Int. J. Toxicol. 2006, $25,451-457$.

[43] J. M. Berg, A. Romoser, N. Banerjee, R. Zebda, C. M. Sayes, Nanotoxicology 2009, 3, 276-283

[44] L. Peng, X. He, P. Zhang, J. Zhang, Y. Li, J. Zhang, Y. Ma, Y Ding, Z. Wu, Z. Chai, Z. Zhang, Int. J. Mol. Sci. 2014, 15, 6072-6085.

[45] Z. Ji, X. Wang, H. Zhang, S. Lin, H. Meng, B. Sun, S. George, T. Xia, A. E. Nel, J. I. Zink, ACS Nano 2012, 6, 5366-5380.

[46] S. Hussain, F. Al-Nsour, A. B. Rice, J. Marshburn, B. Yingling, Z. Ji, J. I. Zink, N. J. Walker, S. Garantziotis, ACS Nano 2012, 6, 5820-5829.

[47] S. Mittal, A. K. Pandey, Biomed. Res. Int. 2014, Article ID 891934.

[48] D. O. Raemy, L. K. Limbach, B. Rothen-Rutishauser, R. N Grass, P. Gehr, K. Birbaum, C. Brandenberger, D. Günther, W. J. Stark, Eur. J. Pharm. Biopharm. 2011, 77, 368-375.

[49] R. Frick, B. Müller-Edenborn, A. Schlicker, B. Rothen-Rutishauser, D. O. Raemy, D. Günther, B. Hattendorf, W. J. Stark, B. Beck-Schimmer, Toxicol. Lett. 2011, 205, 163-172.

[50] J. D. Weaver, C. L. Stabler, Acta BioMater. 2015, 16, 136-144.

[51] A. U. Kura, S. Fakurazi, M. Z. Hussein, P. Arulselvan, Chem. Cent. J. 2014, 8, 46-53; J. T. Dahle, Y. Arai, Int. J. Environ. Res. Public Health 2015, 12, 1253-1278.
[52] J. Y. C. Ma, S.-H. Young, R. R. Mercer, M. Barger, D Schwegler-Berry, J. K. Ma, V. Castranova, Toxicol. Appl. Pharmacol. 2014, 278, 135-147; S. J. Snow, J. McGee, D. B. Miller V. Bass, M. C. Schladweiler, R. F. Thomas, T. Krantz, C. King, A. D. Ledbetter, J. Richards, J. P. Weinstein, T. Conner, R. Willis, W. P. Linak, D. Nash, C. E. Wood, S. A. Elmore, J. P. Morrison, C. L. Johnson, M. I. Gilmour, U. P. Kodavanti, Toxicol. Sci. 2014, 142, 403-417.

[53] H.-J. Eom, J. Choi, Toxicol. Lett. 2009, 187, 77-83.

[54] M. Auffan, J. Rose, T. Orsiere, M. De Meo, A. Thill, O. Zeyons, O. Proux, A. Masion, P. Chaurand, O. Spalla, A. Botta, M. R. Wiesner, J.-Y. Bottero, Nanotoxicology 2009, 3, 161-171.

[55] M. Darroudi, M. Hakimi, M. Sarani, R. K. Oskuee, A. K. Zak, L. Gholami, Ceram. Int. 2013, 39, 6917-6921.

[56] M. Darroudi, S. J. Hoseini, R. K. Oskuee, H. A. Hosseini, L. Gholami, S. Gerayli, Ceram. Int. 2014, 40, 7425-7430.

[57] E.-J. Park, W.-S. Cho, J. Jeong, J.-h. Yi, K. Choi, Y. Kim, K. Park, J. Health Sci. 2010, 56, 387-396.

[58] A. Gojova, J.-T. Lee, H. S. Jung, B. Guo, A. I. Barakat, I. M. Kennedy, Inhalation Toxicol. 2009, 21, 123-130.

[59] A. Sehgal, Y. Lalatonne, J.-F. Berret, M. Morvan, Langmuir 2005, 21, 9359-9364; M. Safi, H. Sarrouj, O. Sandre, N. Mignet, J.-F. Berret, Nanotechnology 2010, 21, 145103.

[60] M. Darroudi, M. Sarani, R. K. Oskuee, A. K. Zak, M. S. Amiri, Ceram. Int. 2014, 40, 2863-2868.

[61] S. M. Hirst, A. S. Karakoti, R. D. Tyler, N. Sriranganathan, S. Seal, C. M. Reilly, Small 2009, 5, 2848-2856.

[62] S. S. Hardas, D. A. Butterfield, R. Sultana, M. T. Tseng, M Dan, R. L. Florence, J. M. Unrine, U. M. Graham, P. Wu, E. A. Grulke, R. A. Yokel, Toxicol. Sci. 2010, 116, 562-576.

[63] L. Alili, M. Sack, A. S. Karakoti, S. Teuber, K. Puschmann, S. M. Hirst, C. M. Reilly, K. Zanger, W. Stahl, S. Das, S. Seal, P. Brenneisen, Biomaterials 2011, 32, 2918-2929.

[64] R. A. Yokel, J. M. Unrine, P. Wu, B. Wang, E. A. Grulke, Environ. Sci.: Nano 2014, 1, 549-560.

[65] V. C. Minarchick, P. A. Stapleton, D. W. Porter, M. G. Wolfarth, E. Çiftyürek, M. Barger, E. M. Sabolsky, T. R. Nurkiewicz, Cardiovasc. Toxicol. 2013, 13, 323-337.

[66] J. Colon, L. Herrera, J. Smith, S. Patil, C. Komanski, P. Kupelian, S. Seal, D. W. Jenkins, C. H. Baker, Nanomed.-Nanotechnol. 2009, 5, 225-231.

[67] F. Pagliari, C. Mandoli, G. Forte, E. Magnani, S. Pagliari, G. Nardone, S. Licoccia, M. Minieri, P. Di Nardo, E. Traversa, ACS Nano 2012, 6, 3767-3775.

[68] S. Patil, S. Kuiry, S. Seal, R. Vanfleet, J. Nanopart. Res. 2002, 4, 433-438; M. Das, S. Patil, N. Bhargava, J.-F. Kang, L. M. Riedel, S. Seal, J. J. Hickman, Biomaterials 2007, 28, 19181925.

[69] A. S. Karakoti, S. Singh, A. Kumar, M. Malinska, S. V. N. T. Kuchibhatla, K. Wozniak, W. T. Self, S. Seal, J. Am. Chem. Soc. 2009, 131, 14144-14145.

[70] A. S. Karakoti, O. Tsigkou, S. Yue, P. D. Lee, M. M. Stevens, J. R. Jones, S. Seal, J. Mater. Chem. 2010, 20, 8912-8919.

[71] B. D'Angelo, S. Santucci, E. Benedetti, S. Di Loreto, R. Phani, S. Falone, F. Amicarelli, M. Ceru, A. Cimini, Curr. Nanosci. 2009, 5, 167-176.

[72] T. Xia, M. Kovochich, M. Liong, L. Mädler, B. Gilbert, H. Shi, J. I. Yeh, J. I. Zink, A. E. Nel, ACS Nano 2008, 2, 2121 2134.

[73] X. Zhou, L. L. Wong, A. S. Karakoti, S. Seal, J. F. McGinnis, C. Emanueli, PLOS ONE 2011, 6, e16733.

[74] P. Skehan, R. Storeng, D. Scudiero, A. Monks, J. McMahon, D. Vistica, J. T. Warren, H. Bokesch, S. Kenney, M. R. Boyd, J. Natl. Cancer Inst. 1990, 82, 1107-1112.

[75] T. Decker, M. L. Lohmann-Matthes, J. Immunol. Methods 1988, 115, 61-69.

[76] F. Denizot, R. Lang, J. Immunol. Methods 1986, 89, 271-277.

[77] R. Kikkawa, T. Yamamoto, T. Fukushima, H. Yamada, I. Horii, J. Toxicol. Sci. 2005, 30, 61-72. 
[78] T. Xia, M. Kovochich, M. Liong, J. I. Zink, A. E. Nel, ACS Nano 2008, 2, 85-96.

[79] N. Ould-Moussa, M. Safi, M.-A. Guedeau-Boudeville, D. Montero, H. Conjeaud, J.-F. Berret, Nanotoxicology 2014, 8, $799-811$.

[80] A. Y. Estevez, J. S. Erlichman, Nanomedicine 2014, 9, 14371440.
[81] Y. Zhang, W. Wei, G. K. Das, T. T. Y. Tan, J. Photochem. Photobiol. C 2014, 20, 71-96.

[82] M. Sack, L. Alili, E. Karaman, S. Das, A. Gupta, S. Seal, P. Brenneisen, Mol. Cancer Ther. 2014, 13, 1740-1749. 